\title{
Diet and Status at Chalcatzingo: Some Empirical and Technical Aspects of Strontium Analysis
}

\author{
MARGARET J. SCHOENINGER \\ Department of Anthropology. The University of Michigan, Ann Arbor, Michigan 48109
}

\author{
MILDRED TROTTER AWARD-1978 \\ For an outstanding student paper
}

\section{KEY WORDS Strontium analysis . Dietary reconstruction}

\begin{abstract}
Determination of the levels of particular trace elements preserved in bone provides a potential pathway for reconstructing the diet of extinct primate species and archaic human groups. Strontium is one of the most useful trace elements for dietary reconstruction but several empirical properties of strontium must be considered during the interpretation of results. (1) Strontium is distributed unevenly throughout the physical environment. (2) Plants, in general, do not discriminate against strontium. (3) During ionic transfer across biological membranes, strontium is discriminated against by terrestrial vertebrates. (4) It is unlikely that strontium would be selectively removed from bone mineral during diagenesis.

A particular difficulty in trace element analysis is caused by interaction between analytical technique and sample matrix. To assess this problem the skeletal population from Chalcatzingo was analyzed by two techniques: atomic absorption spectrometry and neutron activation analysis. The results from the two techniques compared favorably indicating that the pattern of bone strontium levels could be accepted as an accurate reflection of the distribution of bone strontium within the population.

After demonstrating the internal accuracy of the results, the bone strontium level and position of social rank within Chalcatzingo were compared. Ethnographic and archaeological evidence on chiefdoms and states indicate that dietary differences in the amount of meat consumed occur between social ranks. The relative social ranks were reconstructed by using a "pattern analysis" of the burial goods accompanying each individual. The individuals accompanied by jade had the lowest mean bone strontium level $(\bar{X}=532)$. Those individuals buried with a shallow dish had a slightly higher level $(\overline{\mathrm{X}}=635)$. A third group, which had no grave goods, had the highest mean bone strontium level $(\overline{\mathrm{X}}=700)$ which suggests that their diet contained less meat than was available to the rest of the community.
\end{abstract}

Dietary reconstruction is an important aspect of anthropological research, and several recent theories concerning primate morphological and social evolution have been based on strategies of food procurement. Cartmill ('72, '74) suggested that a number of distinctive primate morphological traits may be best explained as an adaptation to visual predation on insects. Jolly ('70) proposed the "seed-eater hypothesis" as a causal model for hominid differentiation. Previously, Robinson ('63) divided australopithecines into two dietary groups, herbivores and omnivores, suggesting that only one of these groups, the omnivores, led to modern Homo sapiens. Even within our species an association has been noted between strategies in human food procurement and level of social organization (White, '49; Ser- 
vice, '71; Binford, '72). Archaeological evidence indicates that shifts in strategies of human food procurement are of ten associated with major changes in cultural orientation. Although there is disagreement about the causal relationship (see papers in Megaw, '77; Reed, '78), the development of permanent villages in the Near East, for example, is associated with the shift to dependence on wild and then domestic grains (Flannery, '72, '73; Braidwood, '72, '73; Oates, '73, '77). One way to test hypotheses generated by these theories and observed associations is to reconstruct the diet of the population of interest.

One of the most promising methods for dietary reconstruction is based on the relative amount of the trace element strontium in bone. This method was first proposed by Toots and Voorhies ('65), who were able to discriminate between Pliocene herbivorous and carnivorous mammals by differences in the relative amount of strontium in their skeletons. Brown ('73, '74) first applied this approach to the study of human populations, and it has since been used by Gilbert ('75) and Szpunar ('77) with varying degrees of success. Because strontium analysis promises to provide important dietary information, and because there has been some uncertainty about the method's accuracy, it was felt that a thorough investigation was necessary.

\section{MATERIALS AND METHODS}

The skeletal material chosen for this project is from the human population which inhabitated Chalcatzingo, Morelos, Mexico, during the period 1150-550 B.C. The most important reason for choosing Chalcatzingo as a study site was because archaeological evidence sug. gests that it was a chiefdom (Grove et al., '76); thus it should present some evidence of internal social ranking (Wright and Johnson, '75; Peebles and Kus, '77). Ethnographic and archaeological evidence from Africa, the Philippines, North America, and Mesoamerica indicate that dietary differences in the relative amount of meat consumed often occur between different social ranks (Spores, '65; Haviland, '67; Hatch and Willey, '74; Hatch, '76). Therefore, dietary differences in the amount of meat were expected between social ranks at Chalcatzingo. Second, the geological situation at the site is especially suited for such a study. Chalcatzingo's inhabitants spent their lives within the confines of this settled, agriculturally based community, thus any non-dietary sources of variation in bone mineral were relatively restricted. In addition, the majority of the burials were recovered from an area which is now, and was then, drained by one small stream so that all skeletons were treated to similar post-burial effects. Third, a large collection of skeletons from Chalcatzingo $(\mathrm{N}=91)$ was made available to me by Dr. David Grove of the University of Illinois. Grove's long-term program of excavation at Chalcatzingo has uncovered this relatively large number of burials from a well defined temporal sequence. For all these reasons, Chalcatzingo made a good test case for the investigation of the use of bone strontium levels in reconstructing diet.

The relative status of individuals buried at Chalcatzingo was determined by the use of a "pattern analysis" of mortuary remains. The analysis depends on the recognized correlation between the complexity of mortuary ritual and the level of social complexity (Childe, '51; Saxe, '70; Peebles, '71; Binford, '72; Hatch, '76). Central to this type of analysis is an assumption that the mortuary ritual accorded an individual reflects the social position of that individual during life. Based on this assumption, the items buried with each individual should provide an indication of the person's status during life. Ward's method of cluster analysis was used to show association and patterns among the items that accompanied each burial. This method was used because it chooses the grouping of items that minimizes within cluster variance for fusion of existing clusters (Sneath and Sokol, '73; Peebles, '74). A strong argument for this type of cluster analysis is included in Cormack (71). The MIDAS statistical package, provided by the Statistical Research Laboratory at the University of Michigan, was used to reveal the pattern of clusters. The burial items used in the clustering procedure in. cluded nine types of ceramics, jade, ground stone, figurines, and a last category which included unique items such as a hematite mirror (listed in Merry, '75). The data were retained in their original form as counts within each of the 13 categories; Euclidean Distance was used as the measure of similarity. Only adults were used in this part of the analysis because only adults were used in the comparison of diet by status. In addition, the only time period that provided a large enough sample size for clustering was Phase C (Middle Formative); therefore, only burials from this phase 
were included. These two restrictions reduced the sample for the cluster analysis to 43 individuals.

\section{Empirical and technical aspects of strontium analysis}

There are two aspects of trace element analysis that deserve separate discussion. The first includes the empirical properties of strontium within the food chain, and the second aspect is a technical one. Each is important, and each must be considered before any reasonable interpretation of results is possible. First, I will discuss the empirical properties, which include: (1) the movement of strontium through the physical environment, (2) strontium uptake by plants, (3) strontium metabolism by animals, and (4) the diagenetic effects on bone after the death of an animal. Technical aspects are discussed in the final part of this section.

\section{Strontium in the physical environment}

Strontium behaves throughout the geological cycle in much the same way as calcium because of its similarity in electron configuration, ionization energy and ionic size. Calcium and strontium however, are not necessarily present in the same ratio between geographic regions, nor is either element distributed evenly throughout the physical environment (Odum, '51).

The initial distribution of strontium in soils should determine the amount available for uptake by plants, but the amount of strontium in ground water is a blend of the amount of strontium within different soils in a drainage basin. It is this blend which actually determines the amount of strontium available for uptake by plants (Menzel and Heald, '59). Since the entire area of Chalcatzingo was drained by a single small stream, the strontium level in local water supplies was assumed to be constant.

\section{Strontium uptake by plants}

There appears to be little discrimination against strontium in favor of calcium by plants (Bowen and Dymond, '55; Comar et al., '57). Because plants are closed systems without mechanisms for the excretion of trace elements, however, continued movement of strontium from soil through the plant stem into the leaves and storage organs results in higher concentration of the element in the latter than in stems (Vose and Koontz, '55;
Schroeder et al., '72). In addition, different plant-types (grasses versus shrubs) accumulate different amounts of strontium. Toots and Voorhies ('65) were able to discriminate between herbivorous browsers and grazers (identified by tooth morphology) by the higher strontium levels in the former. Such relative differences in the amount of strontium contained by different plant-types and by different parts of plants (stems versus leaves) must be considered when trying to make very detailed interpretations of diet from trace ele. ment analysis. However, this level of detail was not necessary in this project, and in any case, all plants and parts of plants contain far more strontium than is contained within animal flesh from the same geographical area (discussed more thoroughly below). If all members of the Chalcatzingo community shared the vegetable portion of the diet, and if it was the amount of meat (containing almost no strontium) in the diet which varied, the difference in strontium content in plant types and parts should not affect the results significantly.

\section{Strontium metabolism by animals}

The amount of strontium deposited in the body parts of animals depends on biological factors and on the amount of the element available to the organism. Invertebrates appear to incorporate strontium in a fashion that is different from that of vertebrates. There is evidence that strontium becomes concentrated in the flesh of marine and fresh water molluscs and crustaceans (Odum, '57; Ophel, '63; Schroeder et al., '72; Kulebakina, '75). Marine vertebrates have higher levels of strontium in their skeletons than terrestrial vertebrates (Rosenthal, '63; Berg, '72). One can suspect that lack of proper consideration of this fact led Wessen et al. (77a,b) to question the use of bone strontium analysis in dietary reconstructions. Terrestrial vertebrates incorporate strontium in their skeletons in direct proportion to the amount of this element in their diet (Comar et al., '55; Lough et al., '63; Comar and Wasserman, '64). Although the majority of dietary strontium is excreted renally, with additional small losses occurring due to lactation and placental transfer in females (Comar and Wasserman, '64), a constant, though small, percentage passes into the blood stream. The amount of strontium in blood is then available for incorporation into bone mineral. Virtually all of the strontium 
actually stored in the body is found in the skeletal system (Schroeder et al., '72); therefore, animal flesh provides almost no strontium when it is included in a diet. An herbivore's diet provides a relatively large amount of strontium since plant material contains about three times the amount of strontium as does animal flesh (Schroeder et al., '72). A small percentage of the herbivore's dietary strontium is deposited in its skeletal sys. tem. An omnivore from the same geographic region should have a lower bone strontium level because the meat in its diet contains virtually no strontium. A carnivore should have the least amount of bone strontium because much more of its diet is meat (Toots and Voorhies, '65; Brown, '73; Gilbert, '75).

More specific information about how stron. tium is distributed within an individual and between individuals of a species must be considered. Virtually all of the strontium retained in the skeleton is sequestered in the mineral portion of bone (Parker and Toots, '70; Spadaro et al., '70). There are differences of opinion on the incorporation of strontium by bone mineral (Comar et al., '57; Neuman et al., '63; Marchall et al., '73; Reeve and Hesp, '76), although most authors agree that the amount of ionic exchange decreases within hydroxyapatite during its maturation process. This lowering of exchangeability may be due to improved crystallization (Neuman et al., '63; Termine and Posner, '67), to increasing bone mineralization (McLean and Urist, '68) or to a combination of these two factors, but the result is that once bone crystal maturity is attained strontium is not selectively removed from bone mineral. The crystal chemistry of hydroxyapatite is still a matter of debate (Termine and Posner, '67; Posner, '69, '73, '77; Blumenthal and Posner, '73; Posner and Betts, '75; Posner et al., '75, '76; Boskey and Posner, '76, '77; Blumenthal et al., '77), but other studies provide indirect evidence on the consequences of bone mineral metabolism on the distribution of strontium throughout the skeleton.

Studies on bone strontium levels between bones of an individual indicate that there is no difference other than that expected from measurement error (Hodges et al., '50; Thurber et al., '58; Yablonskii, '71, '73; Wessen, '77b). After prolonged administration of a strontium rich diet, Bang and Baud (72) found that strontium was evenly distributed in bone from all areas of the body. Therefore, it appears that bone mineral in any portion of the body reflects in the same manner toward strontium. Very little research has been devoted to the mapping of strontium distribution within one bone, but my own work using the electron microprobe to measure strontium, calcium, and phosphorus distributions across bone sections indicates that strontium partitioning probably does not exist (Schoeninger, '79). These results must be considered as tentative because of the difficulties involved in quantitative microprobe analysis for trace elements in biological materials (Boyde et al., '61; Hall, '68), but it does not seem likely that a randum choice of bone area for analysis of strontium should provide a source of error.

The evidence is inconclusive for age dependent differences in strontium incorporation. Some researchers report that bone strontium levels are higher in children than in adults (Lengeman, '63; Lough et al., '63; Loutit, 67; Brown, 73). Others believe that there is no age dependent difference except in fetal bone (Hodges et al., '50; Turekian and Kulp, '56; Alexander and Nusbaum, '59; Szpunar, '77). Still others believe that bone strontium levels are higher in adults than in children (Bedford et al., '60; Sowden and Stitch, '57). Because of these diverse opinions, a consideration of the ages of the individuals within the sample is most important. For the Chalcatzingo sample, only adults were used for comparison of strontium levels to status levels although the complete sample was used during consideration of the accuracy of the techniques.

In order to decide if dietary differences between social ranks actually occurred at Chalcatzingo, an estimate was required of the amount of normal variation that occurs in bone strontium levels among individuals on one dietary regime. Toots and Voorhies ('65: p. 854) have reported coefficients of variation between $3.0(\overline{\mathrm{X}}=477, \mathrm{SD}=15, \mathrm{~N}=4)$ and 6.0 $(\overline{\mathrm{X}}=526, \mathrm{SD}=34, \mathrm{~N}=10)$ for Pliocene vertebrates. Gilbert ('75: pp. 241, 242) has reported coefficients of variation of 16.0 and 15.0 for the human population at Dickson Mound (Female $\overline{\mathrm{X}}=187, \mathrm{SD}=29, \mathrm{~N}=39$; Male $\bar{X}=194, S D=30, N=36$ ). Such variation is a result of two factors: metabolic difference between individuals and measurement error. It is impossible to eliminate the second factor, but it was minimized by using the same sample preparation and analytical procedure on all samples. An estimate of normal variation in bone strontium levels requires analysis of a 
population in which the diet is known and is the same for all individuals. Although, ideally, this sample should be a skeletal population of humans whose diet was known and was uniform, such an ideal was impossible to realize. For this reason, a sample of mink $(\mathrm{N}=35$, donated by Dr. Richard Aulerich of Michigan State University) was used to calculate the estimate. Because the mineral portion of mink bone is hydroxyapatite as is the bone mineral of humans, and because all hydroxyapatite appears to react similarly to strontium, the error introduced by using an animal other than a human should not greatly affect the estimation of the coefficient of variation. The coefficient of variation within this sample was $19.26(\bar{X}=270, S D=52)$. Since this coefficient is larger than those reported previously, the value of 19.26 can only overestimate the expected variation. Given a choice, the error introduced by using an overestimate is preferable to using an underestimate. The use of the latter might lead to unwarranted subdivisions of a distribution of bone strontium levels with the assumption that these divisions represented real dietary differences, whereas the former gives a conservative measure of real dietary differences. Thus a coefficient of approximately $20 \%$ was expected within a human population if all individuals ingested the same diet.

A final significant question concerning metabolism is: could metabolic differences between species affect the percentage of strontium crossing into the blood stream thus affecting deposition independently of diet and thereby affecting the mean strontium level? The work of Alexander et al. ('56) which compared rats and mice fed the same diet with guinea pigs fed a diet high in strontium suggests that species-specific metabolic factors are of an order of magnitude lower than those produced by dietary differences.

\section{Diagenesis}

Finally, there must be some discussion of diagenetic effects-postmortem chemical changes in bone composition. Because strontium is almost completely restricted to the mineral portion of bone, the processes acting on the organic component affect the results of strontium analysis only by altering the weight of bone. To counteract the effects of contamination and differential weight loss the bone to be analyzed must be cleaned, preferably in an ultrasonic cleaner, to remove soil and then ashed to remove whatever organic matter remains (see also Brown and Keyzer, '78). Ashing eliminates any uncertainty concerning the amount of organic matter which has been removed diagenetically.

The cationic position filled by strontium and calcium in bone mineral appears generally to be unaffected by diagenesis over a wide range of conditions. Parker (n.d.) found no difference in the strontium content of enamel, dentin, and bone of fossil Subhyracodon. If postmortem chemical changes had occurred, the denser enamel should have had a different composition than the other two materials since it would be less subject to chemical alteration. Wyckoff and Doberenz ('68) compared the strontium content of animal bone from early human sites in the western United States, Pleistocene animals from California and Arizona, Tertiary animals from Arizona, and even older fossils from all over the world. There was no significant difference in bone strontium levels between any time periods. Evidence from investigations of bone mineral metabolism also attest to the stability of the cationic position in bone mineral. The results of in vivo studies indicate that strontium-90 is almost impossible to remove from bone (McLean and Urist, '68). Posner ('69) reports that ionic exchange in highly crystalized, i.e., mature, bone mineral is probably effected by cellular control since chemical diffusion is restricted due to the removal of water during mineralization. This control is, of course, removed after death, and in addition, chemical diffusion is still restricted since the crystallinity of bone rises after death of the tissue. Based on the results of these investigations, there appears to be no reason to anticipate that diagenesis would provide a source of error if bone mineral is retained in the sample.

\section{Techniques for measuring bone strontium}

Technical aspects of strontium analysis deserve consideration equal to that given the empirical properties, mainly because of the need to evaluate both accuracy and reliability of results. It is possible that lack of proper evaluation of these items led Boaz and Hampel ('78) to reject the use of bone strontium analysis for dietary reconstruction. The dictionary definition of accuracy is "the degree of conformity of a measure to a standard or a true value"; reliability is "the extent to which an experiment, test, or measuring 
procedure yields the same results on repeated trials." The question of accuracy would be a moot one if it could be assumed that the interaction between analytical technique and sample was the same for every sample. If this were the case, then, all error, i.e., the difference between the "true value" and the result of the analytical technique, would be constant. But there is no reason to believe that the error is necessarily constant between samples within one set, and even less reason to believe that it is constant between different sets of samples. Such is particularly true for the analytical technique most commonly used by anthropologists for trace element analysis, atomic absorption spectrometry (AAS). The requirements necessary to assure accuracy in this technique are difficult to meet in the analysis of bone strontium. These require ments include (1) complete dissolution of the sample, which as Szpunar et al. ('78) have shown is seldom accomplished, (2) absence of interferences of ten caused by the formation of stable compounds between cations and anions in the flame (Perkin-Elmer Manual, '71; Helsby, '74), and (3) absence of ionization of the strontium atoms in the flame. The addition of lanthanum, suggested in the PerkinElmer Manual ('71) cannot remove the interference problem mentioned in (2) because of the large amount of phosphate in bone (Helsby, '74).

The composition of the sample, apart from the strontium content, determines the size of the differential between the "true value" and the result of the analysis. Since there is no reason to expect the composition to be exactly the same from sample to sample, there is no reason to expect the error to be constant. Therefore, even if the technique is reliable (i.e., a single sample analyzed three times gives the same result) this does not mean that two samples with the same result necessarily contain the same amount of strontium. The error may be greater for one sample than the other.

One way to identify and minimize these problems is to analyze the samples by a second technique. If the same pattern is produced, then it can be assumed that the results are reliable and internally accurate. I emphasize "pattern" because the second technique is likely to produce different numerical values since there will be additional interferences in the second technique. The second technique used in this project was neutron activation analysis (NAA). Only a subset of the total sample set was analyzed by NAA because of the cost involved.

For the analysis by AAS, the bone was cleaned, dried to a constant weight, ground in an agate mortar and then ashed at $600^{\circ} \mathrm{C}$ for at least 12 hours. Approximately $500 \mathrm{mg}$ of bone ash were placed in a glass scintillation vial and dissolved in concentrated hydrochloric acid. From each dissolved sample solution $0.1 \mathrm{ml}$ was taken and placed in a poly. styrene vial, and to this $4.0 \mathrm{ml}$ of a stock solution, consisting of $1.0 \%$ lanthanum and $0.5 \%$ potassium in deionized water, were added. The total dilution was $1: 100(1: 2$ in $\mathrm{HCl}, 1: 50$ in stock solution). The solutions were then analyzed by a Jarrel-Ash spectrometer with the following machine parameters:

$$
\begin{array}{lc}
\text { Wavelength } & 460.7 \mathrm{~nm} \\
\text { Fuel } & 30.0 \mathrm{psi} \text { (acetylene) } \\
\text { Support } & 35.0 \mathrm{psi} \text { (nitrous oxide) } \\
\begin{array}{l}
\text { Vertical and horizontal } \\
\text { position of the }
\end{array} & \begin{array}{c}
\text { Set so that the light from } \\
\text { the hollow cathode ray } \\
\text { burner head }
\end{array} \\
& \begin{array}{l}
\text { tube was centered over } \\
\text { the slit in the burner }
\end{array}
\end{array}
$$

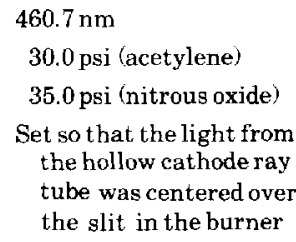

The standards were checked several times during the analysis and each sample was analyzed three times. The average of the three readings was used in the calculation of parts strontium per million parts bone (ppm). This calculation was done by comparing the results produced by the unknown samples with the results produced by the standards. For NAA approximately $50 \mathrm{mg}$ of each sample of bone ash was heat sealed in suprasil quartz tubing which had previously been cleaned by boiling in aqua regia. The samples, a blank, and two standards were irradiated in the reactor pool for 30 hours. Three weeks after removal from the pool each sample was counted for two hours. The radionuclide that was used to measure strontium concentration was strontium$85\left(\mathrm{~T}^{1 / 2}=62.5\right.$ days $)$ which emits gamma rays of $514 \mathrm{keV}$. Again, the results were calculated by comparing the values produced by the unknown samples with the values produced by the standards. A more detailed discussion of materials and methods is included in Schoeninger ('79).

\section{RESULTS}

\section{Strontium analysis}

The distribution patterns of bone strontium levels from the Chalcatzingo sample produced by atomic absorption spectrometry and neutron activation analysis are similar (fig. 


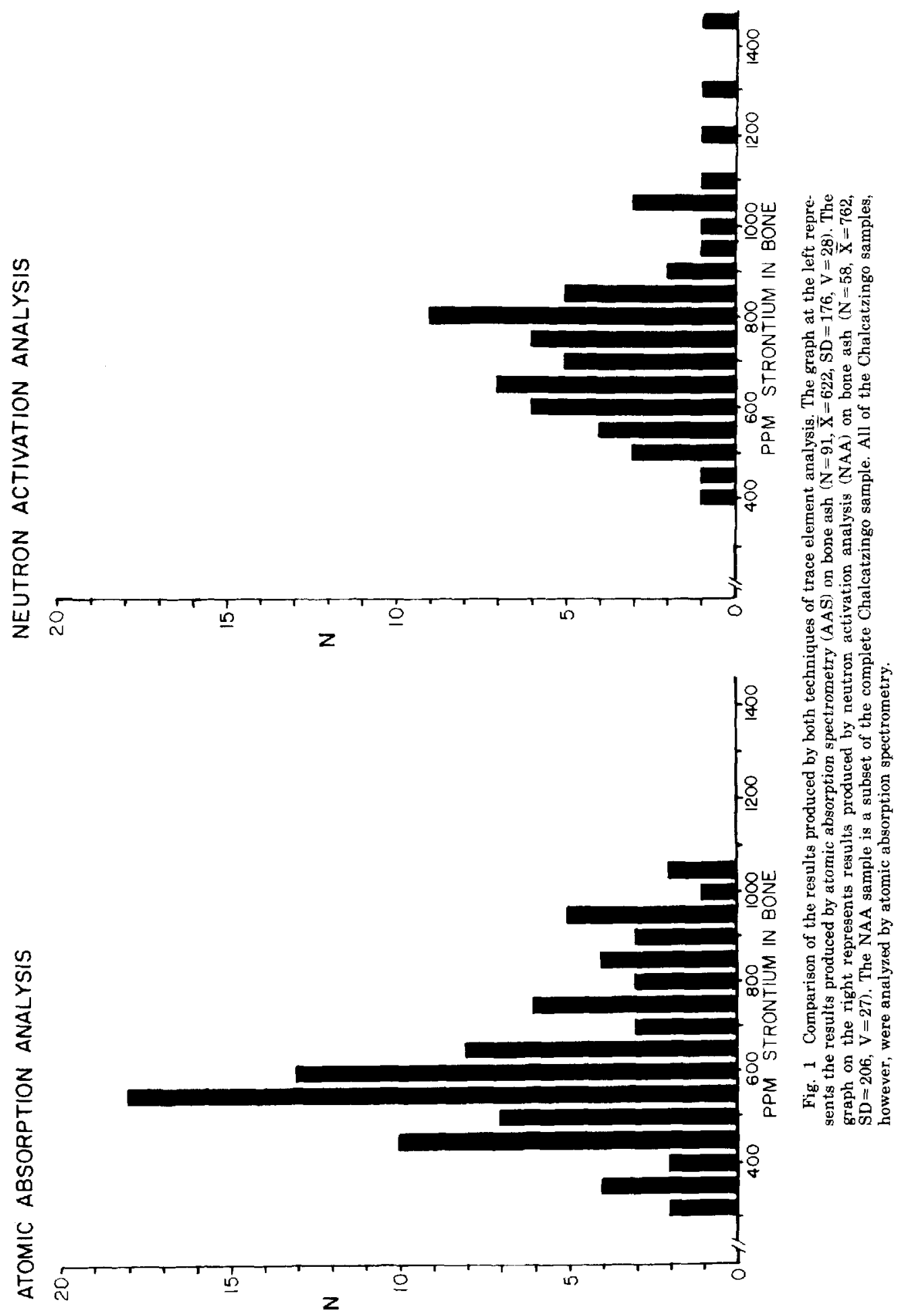




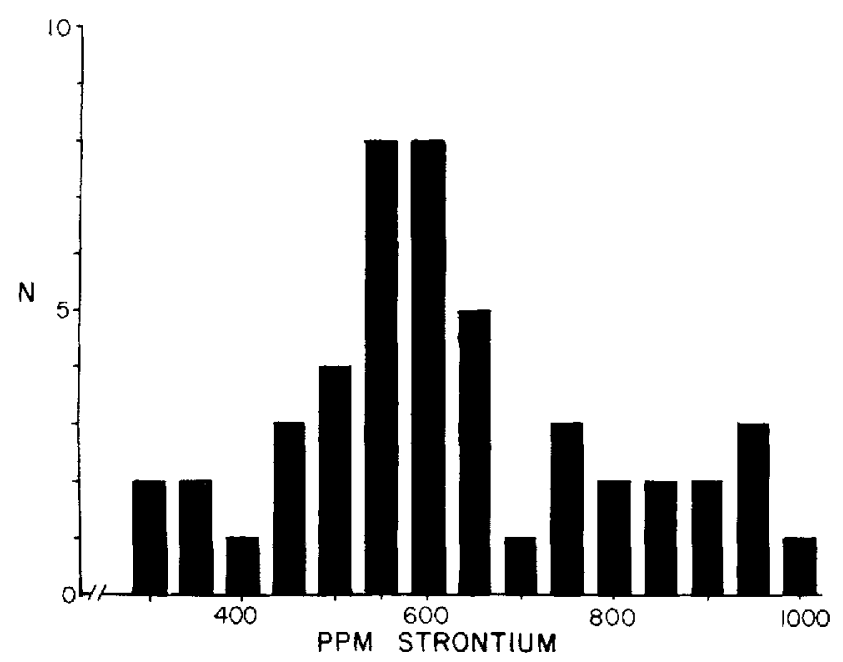

Fig. 2 Distribution of bone strontium levels in adults from Phase $C$ Middle Formative period at Chalcatzingo. The samples were analyzed as dissolved bone ash by atomic absorption spectrometry $(\mathrm{N}=47$, $\overline{\mathrm{X}}=627, \mathrm{SD}=175, \mathrm{~V}=28$ ).

TABLE 1

Comparison of high strontium levels

\begin{tabular}{lcr}
\hline \multicolumn{1}{c}{ Sample } & NAA $^{2}$ & AAS $^{3}$ \\
\hline S39A No. 2 & 1,214 & 947 \\
Area A No. 6 & 1,035 & 940 \\
Cave 1 No. 1 & 1,433 & 1,069 \\
Cave 1 No. 2 & 1,321 & 1,053 \\
Cave 4 No. 2 & 1,081 & 700 \\
T24 No. 5 & 1,072 & 950 \\
T37 No. 1 & 1,019 & 994 \\
T25 III & 591 & 858 \\
T25 VI & 813 & 902 \\
T25 No. 4 & - & 910 \\
T25 No. 15 & - & 936 \\
T37 No. 4 & 750 & 823 \\
N5 No. 1 & - & 853 \\
T20 No. 3 & 919 & 817 \\
PC72 No. 27 & 912 & 900 \\
PC73 No. 6 & 1,065 & 830 \\
T25 No. 11 & - & 927 \\
T21 No. 1 & - & 870 \\
\hline
\end{tabular}

' All values are in parts strontium per million parts bone (ppm).

${ }^{2}$ Above $1,000 \mathrm{ppm}$ Sr is considered a high strontium level.

${ }^{3}$ Above $800 \mathrm{ppm} \mathrm{Sr}$ is considered a high strontium level.

1). Two coefficients of rank correlation were calculated in order to evaluate the similarity of results obtained from the two techniques. These statistics, rather than Pearson's product moment correlation coefficient, were calculated because systematic error, produced by the interaction between sample matrix and analytical technique probably lowered the similarity in the absolute values produced, and because the samples cannot be assumed to be normally distributed. The value of Spear- man's Rho (0.75) indicates that the overall pattern of ranks is similar between techniques, and thereby, supports the conclusion that the pattern is due to the distribution of bone strontium levels (and hence to the distribution of diets) within the population rather than to technique artifact. Kendall Tau-B, based on the relative orderings of pairs of samples, however, has a value of only 0.58 , which suggests that ordering of individual pairs of samples is not sufficiently correlated to rely upon the position of one sample relative to other samples with similar strontium levels.

Each distribution in figure 1 appears to be skewed toward the right, i.e., toward the low meat (high strontium) end of the graph. In fact, the value of the sample statistic for measuring skewness $\left(g_{1}\right)$ in the neutron activation sample is 1.003 and in the atomic absorption sample it is 0.601 . The significance of this deviation from the expected value of the parameter $(0.000)$ was calculated following Sokol and Rohlf ('69: p. 171). A one-tailed $t$-test was used because direction is indicated by the sign of the skewness statistic (in this case it is positive, the direction is toward the right). The probability that the sample analyzed by neutron activation was drawn from a normally distributed populations is less than 0.005 , the probability for the atomic absorption sample is less than 0.01 . These results indicate that the samples were drawn from a population that was not normally distributed 
TABLE 2

Comparison of diets through time

\begin{tabular}{|c|c|c|c|}
\hline Time periods & t-value & $\begin{array}{l}\text { Degrees of } \\
\text { freedom }\end{array}$ & $\begin{array}{l}\text { Significance } \\
\text { one-tailed test }\end{array}$ \\
\hline \multicolumn{4}{|l|}{ Phase $B$ and $B$-C versus } \\
\hline Phase C & 1.21 & 71 & Not significant \\
\hline \multicolumn{4}{|l|}{ Phase $C$ versus } \\
\hline Late Formative & 1.65 & 75 & Not significant \\
\hline \multicolumn{4}{|l|}{ Late Formative versus } \\
\hline Classic and Post-Classic & 0.88 & 17 & Not significant \\
\hline
\end{tabular}

but instead is skewed to the right. The reason for the skewness must be considered.

In general, and with a few exceptions, the same individuals, constitute the group with high bone strontium in both distributions. Table 1 lists the samples that produced high strontium values by each technique. For the atomic absorption results, all specimens with 800 parts strontium per million parts bone $(N=17)$ were considered to have very high strontium levels. This point was picked because it is approximately midway between the mode in the body of the curve and an incipient mode at the high end of the curve. The breakpoint chosen for the neutron activation results was $1,000 \mathrm{ppm}$ strontium $(\mathrm{N}=8)$ for the same reason. A dash indicates that no analysis was performed by neutron activation for that sample. Of the 13 samples that were analyzed by both techniques, seven are ranked high by both techniques (S39A-No. 2, Area A-No. 6, Cave 1-No. 1, Cave 1-No. 2, T24-No. 5, T37-No. 1 , and PC73-No. 6), and two are close enough that the difference may be due to measurement error (T20-No. 3 and PC72-No. 27). Of the four remaining samples, one is a specimen in which the bone ash did not completely dissolve (Cave 4-No. 2) during the sample preparation for atomic absorption, and three are specimens that have neutron activation results lower than the AAS result on the same sample (T25-III, T25-VI, and T37-No. 4). Since these three are the only samples where the NAA result is lower than the AAS result, these NAA values are considered questionable. Because the samples were analyzed by two techniques, and because there is general agreement between the techniques, the high values of these 18 samples are accepted as real rather than as an artifact of a particular analytical technique. Since all samples were analyzed by atomic absorption spectrometry, the results discussed subsequently are those produced by atomic absorption.
The distribution of strontium values has a coefficient of variation that is higher than expected if all individuals had had the same diet $(\mathrm{V}=28$ versus $\mathrm{V}=19$ from the sample of mink, all of whom had the same diet). Presumably, this could be due to the inclusion of children and of individuals from different time periods. The value of the coefficient, however, remains the same ( $V=28$, fig. 2) when children are removed and when the sample is restricted to individuals from one time period Phase $\mathrm{C}$ of the Middle Formative period (750-550 B.C., Grove et al., '76). This time period was chosen for the following discussion because the largest sample of burials were attributed to it $(\mathrm{N}=44$ adults, Merry, '75). It is possible that this variation indicates a change in diet over the 200 year span of Phase $\mathrm{C}$ rather than indicating differential distribution of foodstuffs within a group that was living contemporaneously. A comparison was made of mean bone strontium levels from all time periods. The results of $t$ tests indicate that the mean strontium levels are not significantly different between any of the time periods (table 2 ). In addition, archaeological evidence indicates that Chalcatzingo was a settled, agriculturally based community throughout its existence. Therefore, dietary changes through time cannot account for the distribution of bone strontium levels. When the distribution is divided by removing the ten Phase $\mathrm{C}$ adults with the highest bone strontium levels, the coefficient of variation drops from 28 to $20(\overline{\mathrm{X}}=538, \mathrm{SD}=109)$. This value is almost exactly equal to the expected value $(\mathrm{V}=19)$ for one species subsisting on one dietary regime. These results suggest that during Phase C Middle Formative period at Chalcatzingo there was a group of individuals eating less meat than was available to another, seemingly, contemporaneous group.

\section{Mortuaryanalysis}

Ward's method of cluster analysis revealed 


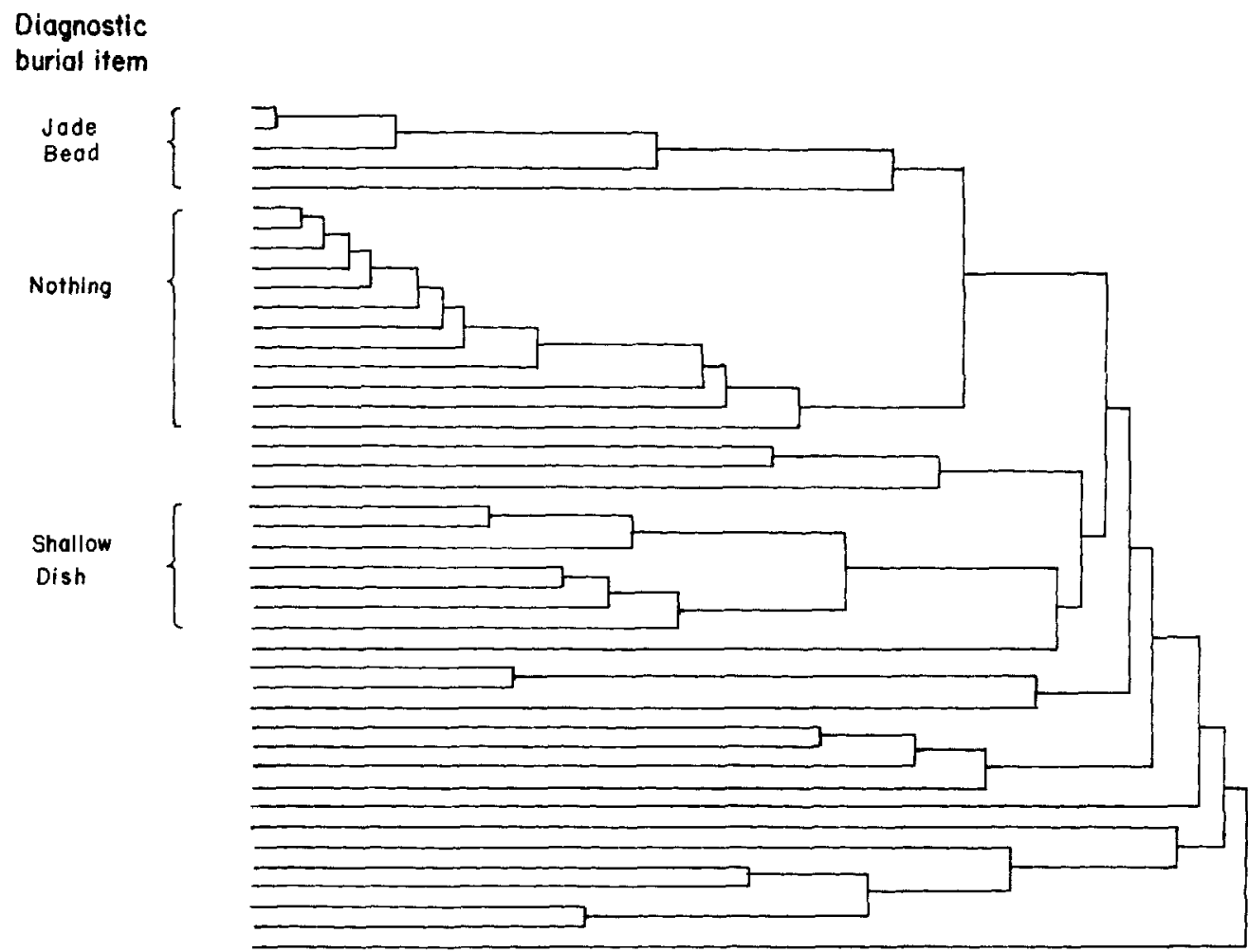

Fig. 3 Results of cluster analysis carried out on the burials from Chalcatzingo. Similarity was calculated using Euclidean Distance. Clusters were combined based upon minimization of within cluster variance. Only adults from Phase C Middle Formative period were included in the analysis. The burial item diagnostic of each cluster is shown at the left and the burials included in each cluster are enclosed within brackets. Reprinted from M. J. Schoeninger, '79.

three distinct burial groups (fig. 3 and table $3)$. Cluster one $(\mathrm{N}=5)$ contains individuals accompanied by jade. Of the individuals in cluster two $(\mathrm{N}=12)$, nine have no grave goods and three are accompanied by non-diagnostic grave goods (one is accompanied by a mano, one by an olla, and the third is accompanied by a hemispherical bowl). Cluster three $(\mathrm{N}=7)$ contains individuals accompanied by one or two shallow dishes and little else. The rest of the burials are either in groups of two or have not been clustered at all, therefore, they will not be discussed.

\section{DISCUSSION}

A comparison of the strontium values with with the pattern of social ranking reveals interesting points of congruence (table 3 ). In general, an attempt to match individual clusters with particular sections of the range of bone strontium values was successful. In the cluster containing individuals accompanied by jade (cluster 1), the mean bone strontium level is $532 \mathrm{ppm}(\mathrm{N}=5,364-666 \mathrm{ppm} \mathrm{Sr})$. The cluster defined by the presence of shallow dishes (cluster 3), has a higher mean bone strontium level of $635 \mathrm{ppm}(\mathrm{N}=7,320-994$ $\mathrm{ppm} \mathrm{Sr}$ ). The cluster containing those individuals who had no burial goods and three individuals (the last three in the cluster 2 list) who had one nondiagnostic artifact accompanying each of them, has the highest mean bone strontium level of $700 \mathrm{ppm}(\mathrm{N}=12,295$ $910 \mathrm{ppm} \mathrm{Sr}$ ). Although the difference between the means is significant in only one case (cluster, versus cluster ${ }_{2}$, table 4), the trend is that expected from the status divisions suggested by the analysis of the mortuary artifacts. Jade is thought by most archaeologists to be a high status item. The bone strontium levels indicate that those individuals (cluster 1) buried with jade at Chalcat- 
zingo probably had a diet containing more meat (demonstrated by lower bone strontium levels) than those individuals in the other clusters. Individuals who were buried with shallow dishes appear to have had diets which contained an intermediate amount of meat and those individuals who were buried without any burial items had diets which, on the average, contained less meat than was normal for the total population.

It is possible that both the dietary differences and the assignment of burial goods were along sex lines. The material from Chalcatzingo was very fragmentary and a determination of sex was impossible in the majority of cases (Merry, '75); therefore, this

TABLE 3

Strontium values for three clusters

\begin{tabular}{|c|c|c|c|}
\hline Sample No. & Cluster No. & $\begin{array}{c}\text { Cluster's } \\
\text { diagnostic item }\end{array}$ & $\begin{array}{l}\text { Strontiurn ppm } \\
\text { (AAS) }\end{array}$ \\
\hline T25 No. 2 & 1 & Jade & 666 \\
\hline T25 No. 10 & 1 & Jade & 364 \\
\hline PC73 No. 3 & 1 & Jade & 581 \\
\hline PC72 No. 24 & 1 & Jade & 475 \\
\hline T25 No. 3 & 1 & Jade & $\begin{array}{r}573 \\
\overline{\mathrm{X}}=532 \\
\mathrm{SD}=116\end{array}$ \\
\hline T25 No. 4 & 2 & Nothing & 910 \\
\hline T25 No. 11 & 2 & Nothing & 927 \\
\hline T25 No. 21 & 2 & Nothing & 731 \\
\hline $\mathrm{T} 25 \mathrm{VI}$ & 2 & Nothing & 902 \\
\hline PC73 No. 1 & 2 & Nothing & 600 \\
\hline PC73 No. 8 & 2 & Nothing & 524 \\
\hline PC72 №. 11 & 2 & Nothing & 529 \\
\hline PC72 No. 17 & 2 & Nothing & 295 \\
\hline T21 No. 1 & 2 & Nothing & 870 \\
\hline PC73 No. 6 & 2 & Nothing & 830 \\
\hline T9B No. 3 & 2 & Nothing & 670 \\
\hline T24 No. 4 & 2 & Nothing & $\begin{array}{r}614 \\
\bar{X}=700 \\
\mathrm{SD}=197\end{array}$ \\
\hline PC72 No. 9 & 3 & Shallow dish & 465 \\
\hline PC73 No. 19 & 3 & Shallow dish & 606 \\
\hline T37 No. 1 & 3 & Shallow dish & 994 \\
\hline PC73 No. 30 & 3 & Shallow dish & 424 \\
\hline T37 No. 4 & 3 & Shallow dish & 823 \\
\hline T23 No. 1 & 3 & Shallow dish & 320 \\
\hline T20 No. 3 & 3 & Shallow dish & $\begin{array}{r}816 \\
\bar{X}=635 \\
S D=248\end{array}$ \\
\hline
\end{tabular}

possibility could not be checked directly. Even if true, however, it would not falsify the basic assumption that both burial items and diet were distributed along status lines; it simply adds sex as one of the qualities that determined status.

It is obvious that there is quite a bit of overlap in ranges of bone strontium values between clusters, and this is to be expected. The only way that completely discrete ranges could possibly occur would be if the diets were discrete, contained no food items shared between social groups, and the possibilities of measurement error could be rejected. The last factor cannot be rejected, and it unlikely that within a population organized as a chiefdom (or probably at any level of social organization) diets between social strata were completely discrete and contained no shared food items.

\section{SUMMARY AND CONCLUSIONS}

The purpose of the project described in this paper was to demonstrate the feasibility of the method using the level of bone strontium as an indicator of diet. The skeletal population from Chalcatzingo, a Formative period agricultural community in the highlands of central Mexico, was used as a test case for the study. This site was chosen because archaeological information on the site's overall size, distribution of buildings, the variability of building type, and the probable presence of craft specialization serve to indicate that Chalcatzingo was organized minimally as a chiefdom. Because of this evidence, it was assumed that some form of social ranking was present. Relative rank of individuals was inferred from the pat. tern of the distribution of mortuary items among the burials.

Ethnographic and archaeological reports from Africa, the Philippines, North America and Mesoamerica suggest that higher ranked groups of individuals in chiefdoms and states have greater access to high status food items, particularly meat, than do the remainder of the population. If such a difference in diet was

TABLE 4

Comparison of cluster means

\begin{tabular}{cccc}
\hline Comparison & t-value & $\begin{array}{c}\text { Degrees of } \\
\text { freedom }\end{array}$ & $\begin{array}{c}\text { Level of } \\
\text { significance }\end{array}$ \\
\hline Cluster, vs cluster $_{2}$ & 2.68 & 15 & 0.02 \\
Cluster, vs cluster $_{3}$ & 0.78 & 10 & Not significant \\
Cluster, vs cluster $_{3}$ & 0.59 & 17 & Not significant \\
\hline
\end{tabular}


present, then individuals of higher rank should have lower bone strontium levels (higher meat intake) than individuals of lower rank.

Before any actual trace element analysis took place, certain empirical properties of strontium and aspects of technique/matrix interaction were considered. First among the empirical properties, the uneven geographical distribution of strontium, was controlled by choosing the Chalcatzingo sample which was from a geographically restricted area. Second, although there are obviously some differences in the incorporation of strontium by various plants and parts of plants, it was concluded that a diet high in vegetable products would provide higher dietary strontium than would a diet containing more meat. Third, consideration of the movement of strontium through the animal portion of the food chain indicates:

a. strontium is deposited in bone in proportion to the amount in diet.

b. once bone crystal maturity is attained, removal of strontium occurs only as a result of osteoclastic activity.

c. strontium is distributed evenly between different bones of the skeletal system.

d. strontium appears to be distributed evenly throughout individual bones.

e. there is, at present, no consensus of opinion on how metabolic rate differences between adults and children affect strontium deposition. Therefore, the total sample including children was used only when evaluating technique accuracy.

$\mathrm{f}$. individual metabolic differences may occur. In order to approximate the amount of variation this could produce independent of diet, a sample of $35 \mathrm{mink}$, was analyzed for bone strontium levels by atomic absorption. All of these animals had been raised on the same diet; therefore, the coefficient of variation of this sample $(V=19)$ was used as the amount of variation expected from one species on one diet.

g. metabolic differences between species produce variations in bone strontium levels of an order of magnitude lower than that produced by dietary differences.

$h$. the two plus cation position filled by strontium in bone mineral is very stable; therefore, diagenesis should not affect bone strontium levels.

Next, the technical basis was discussed. The analytical techniques usually used for trace element analysis all display an interaction with bone matrix. This interaction produces a certain level of error which cannot be assumed to be constant. In order to provide a check on random error, two analytical techniques were used and the results compared. The absolute values produced by the two techniques were not identical due to the matrix-technique interaction, but the two techniques ranked samples in similar relative positions. Therefore, the rank of the sample was considered to be an indicator of the amount of bone strontium in the sample relative to that in other samples rather than the result of technique error.

The coefficient of variation of the Chalcatzingo sample was larger than that expected if only one dietary regime had been present. In addition, the distribution was skewed toward the high strontium (low meat) end of the graph. The shape of the distribution and the size of the coefficient of variation suggest that a group of individuals living in Chalcatzingo was consuming a diet containing less meat than was included in the diet of most community members.

Comparison of the pattern of social ranking, constructed from a mortuary analysis, with the bone strontium levels indicates that this method of dietary reconstruction is feasible. The individuals buried without accompanying mortuary items, who are assumed to be of low rank, are the same individuals who have the highest bone strontium levels. In fact, these individuals are for the most part the ones whose bone strontium levels produce the skewing in the otherwise normal distribution. The group of individuals buried with jade, who are assumed to be of high rank, has a low mean bone strontium level (higher meat intake). Finally, the group buried with shallow dishes, which was assumed to be of rank intermediate between the other two groups has a mean bone strontium level intermediate between the other two groups. Therefore, the bone strontium level does reflect the dietary difference that was expected as a result of differential ranking.

The demonstration provided by this project strongly suggests that the analysis of bone for trace amounts of strontium can provide information relating to diet. Using this method, skeletal material permits an independent check on conclusions based on archaeological evidence, and, when used in conjunction with archaeological material, analysis for the levels of bone strontium can increase our knowledge of the behavior of prehistoric popu- 
lations. In addition, such dietary information would be useful in the investigation of several problems of interest to paleoanthropologists. The australopithecine dietary hypothesis suggested by Robinson ('63) could be tested. The amount of meat actually consumed by Middle and Upper Paleolithic hunters might be determined. Finally, tracing the shift in dietary emphasis through the Mesolithic and into the Neolithic would provide information on the introduction of agriculture into the Near East and Europe.

\section{ACKNOWLEDGMENTS}

I wish to thank Dominic Dziewiatkowski, John Jones, Ward Rigot, Wilbur Bigelow, John Mardinley (University of Michigan), John Eaton, and Elaine Berger (University of Minnesota) for use of their laboratory facilities and equipment. David Grove (University of Illinois) allowed me to take bone samples from all the Chalcatzingo burials; Ann Cyphers and Marcia Merry provided unpublished materials from the Chalcatzingo project. Richard Aulerich (Michigan State University) supplied the sample of mink. Critical comments from C. Loring Brace, Jane Buikstra, Kent Flannery, Philip Gingerich, Christopher Peebles, Charles Rulfs, John Speth, and Milford Wolpoff greatly improved the manuscript. Support for the project was supplied by Research Grant No. 539 from the Phoenix Laboratories of the University of Michigan, Research Grant GS-31017 from the National Science Foundation, and grants from Sigma Xi and the University of Michigan Department of Anthropology and Museum of Anthropology. I thank Simone H. Taylor for typing the manuscript. Comments from an anonymous reviewer improved the manuscript by indicating areas in need of clarification.

\section{LITERATURE CITED}

Alexander, G. V., and R. E. Nusbaum 1959 The relative retention of strontium and calcium in human bone tissue. J. Biol. Chem., 234: 418-421.

Alexander, G. V., R. E. Nusbaum and N. S. MacDonald 1956 The relative retention of strontium and calcium in bone tissue. J. Biol. Chem., 218: 911-919.

Bang, B., and C. A. Baud 1972 Topographic distribution of strontium and its incorporation into bone mineral substance in vivo. Proceedings of the International Con. ference on X-ray Optics and Microanalysis, Sixth annual, G. Shinoda, ed. University of Tokyo Press, Tokyo, Japan, pp. $841-845$.

Bedford, J., G. E. Harrison, W. H. A. Raymond and A. Sutton 1960 The metabolism of strontium in children. Br. Med. J., 1: 589-592.
Berg, A. 1972 Metabolism of calcium and strontium in fresh water fish. IV. Calcium and strontium relations in fishes of two northern Italian lakes and their general radioecological implications. Mem. 1st Ital. Idrobiol. Dott. Marco de Marchi, 29: 145-167.

Binford, L. R. 1972 An Archaeological Perspective. Seminar Press, New York.

Blumenthal, N. C., F. Betts and A. S. Posner 1977 Stabilization of amorphous calclum phosphate by $\mathrm{Mg}$ and ATP. Calcif. Tissue Res., 23: 245-250.

Blumenthal, N. C., and A. S. Posner 1973 Hydroxyapatite: mechanism of formation and properties. Calcif. Tissue Res., 13: 235-242.

Boaz, N. T., and J. Hampel 1978 Strontium content of fossil tooth enamel and diet in early hominids. J. Paleont., 52: 928-933.

Boskey, A. L., and A. S. Posner 1976 Extraction of a calcium-phospholipid-phosphate complex from bone. Calcif. Tissue Res., 19: 273-283.

Boskey, A. L., and A. S. Posner 1977 The role of synthetic and bone extracted calcium-phospholipid-phosphate complexes in hydroxyapatite formation. Calcif. Tissue Res., 23: $251-258$.

Bowen, H. J. M., and J. A. Dymond 1955 Strontium and barium in soils and plants. Proc. R. Sac. Lond. (Biol.), 144: $355-368$.

Boyde, A., V. R. Switzur and R. W. Fearnhead 1961 Application of the scanning electron-probe x-ray microanalyzer to dental tissues. J. Ultrastruct. Res., 5: 201-207.

Braidwood, R. J. 1972 Prehistoric investigations in southwestern Asia. Proc. Am. Philos. Soc., 116: 310-320.

1973 The early village in southwestern Asia. J. Near Eastern Stud., 32: 34-39.

Brown, A. B. 1973 Bone Strontium as a Dietary Indicator in Human Skeletal Populations. Doctoral Dissertation, University of Michigan, Ann Arbor.

1974 Bone strontium as a dietary indicator in human skeletal populations. Contrib. Geol., 13: 47-48.

Brown, A. B., and H. Keyzer 1978 Sample preparation for strontium analysis of ancient skeletal remains. Contrib. Geol., 16: 85-87.

Cartmill, M. 1972 Arboreal adaptations and the origin of the order Primates. In: The Functional and Evolutionary Biology of Primates. R. Tuttle, ed. Aldine-Atherton Publ. Co., pp. 97-122.

- 1974 Rethinking primate origins. Science, 184: $436-443$.

Childe, V. G. 1951 Social Evolution. Watts and Co. Publ.

Comar, C. L., R. S. Russell and R. H. Wasserman 1957

Strontium-calcium movement from soil to man. Science, 126: $485-492$.

Comar, C. L., and R. H. Wasserman 1964 Strontium. In: Mineral Metabolism. C. L. Comar and F. Bronner, eds. Academic Press, New York, Vol. 2, Part A, pp. 523-572.

Comar, C. L., I. B. Whitney and F. W. Lengemann 1955 Comparative utilization of dietary strontium-90 and cal cium by developing rat fetus and growing rat. Proc. Soc. Exp. Biol. Med., 88: 232-236.

Cormack, R. M. 1971 A review of classification. J. R. Stat. Soc, A, 134: 321-367.

Flannery, K. V. 1972 The origins of the village as a settlement type in Mesoamerica and the Near East: a comparative study. In: Man, Settlement, and Urbanism. P. Ucko, R. Tringham and G. W. Dimbleby, eds. Dimbleby Gerald Duck worth and Co. Publ., London, pp. 24-53.

- 1973 The origins of agriculture. Ann. Rev. Anthrop., 2: $271-310$.

Gilbert, R. I. 1975 Trace Element Analyses of Three Skele- 
tal Amerindian Populations at Dickson Mounds. Doctoral Dissertation, University of Massachusetts, Amherst.

Grove, D. C., K. G. Hirth, D. E. Buge and A. M. Cyphers 1976 Settlement and cultural development at Chalcatzingo. Science, 192: 1203-1210.

Hall, T. 1968 Some aspects of the microprobe analysis of biological specimens. In: Quantitative Electron Probe Micro-analysis. K. F. J. Heinrich, ed. NBS Spec. Pub. 298, pp. 269-299.

Hatch, J. W. 1976 Status in Death: Principles of Ranking in Dallas Culture Mortuary Remains. Doctoral Dissertation. Pennsylvania State University, University Park.

Hatch, J. W., and P. S. Willey 1974 Stature and status in Dallas society. Tenn. Arch., 30: 107-131.

Haviland, W. A. 1967 Stature at Tikal, Guatemala: implications for ancient Maya demography and social organization. Am. Antiq., 32: 316-325.

Helsby, C. A. 1974 Determination of strontium in human tooth enamel by atomic absorption spectrometry. Anal. Chim. Acta, 69: 259-265.

Hodges, R. M., N. S. MacDonald, R. Nusbaum, R. Stearns, F. Ezmirlian, P. Spain and C. MacArthur 1950 Strontium content of human bones. J. Biol. Chem., 185: 519-524.

Jolly, C. J. 1970 The seed-eaters: a new model of hominid differentiation based on a baboon analogy. Man, 5: 5-26.

Kulebakina, L. G. 1975 Strontium-90 in the cystoseiric biocenosis of the Black Sea shelf zone. In: Self-Purification, Bioproductivity, and Protection of Reservoirs and Currents of Water in the Ukraine. A. V. Topachevskii, ed. Naukova Dumka Publ., Kiev, USSR, pp. 102-104.

Lengeman, F. W. 1963 Overall aspects of calcium and strontium absorption. In: The Transfer of Calcium and Strontium Across Biological Membranes. R. H. Wasserman, ed. Academic Press, New York, pp. 85-96.

Lough, A. A., J. Rivera and C. L. Comar 1963 Retention of strontium and calcium and phosphorus in human infants. Proc. Soc. Exp. Biol. Med., 112: 631.

Loutit, J. F. 1967 Strontium-90 from fall-out in human bone. In: Strontium Metabolism. J. M. A. Lenihan, J. F Loutit and J. G. Martin, eds. Academic Press, New York, pp. 41-45.

Marchall, J. H., J. Liniecki, E. L. Lloyd, G. Marotti, C. W. Mays, J. Rundo, H. A. Sissons and W. S. Snyder 1973 Alkaline earth metabolism in adult man. Health Phys. 24: $125-221$.

McLean, F. C., and M. R. Urist 1968 Bone: An Introduction to the Physiology of Skeletal Tissue. Third ed. University of Chicago Press, Chicago, Illinois.

Megaw, J. V. S., ed. 1977 Hunters, Gatherers and First Farmers Beyond Europe. Leicester University Press, New Jersey.

Menzel, R. G., and W. R. Heald 1959 Strontium and calcium contents of crop plants in relation to exchangeabie strontium and calcium of the soil. Soil Sci. Soc. Am. Proc., 23: $110-112$.

Merry, M. P. 1975 Investigation of a Middle Formative Area of Burials: Chalcatzingo, Morelos, Mexico. Master's Thesis, University of the Americas, Mexico City.

Neuman, W. F., R. Bjornerstedt and B. J. Mulryan 1963 Synthetic hydroxyapatite crystals. II. Aging and strontium incorporation. Arch. Biochem. Biophys., 101: 215-224.

Oates, J. 1973 The background and development of early farming communities in Mesopotamia and the Zagros. Proc. Prehist. Soc., 39: 147-181.

1977 Mesopotamian social organization: ar chaeological and philological evidence. In: Evolution of Social Systems. J. Friedman and M. J. Rowlands, eds. Duckworth and Co. Publ., London, pp. 457-485.
Odum, J. T. 1951 The stability of the world strontium cycle. Science, 114: 407-411.

- 1957 Strontium in natural waters. Texas Univ. Inst. Marine Sci. Publ., 4: 22-37.

Ophel, I. L. 1963 The fate of radiostrontium in a freshwater community. In: Radioecology. V. Schultz and A. W. Klement, eds. Chapman and Hall Publ., London, pp. 213-216.

Parker, R. B., and H. Tonts 1970 Minor elements in fossil bones. Geol. Sur. Am. Bull., 81: 925-932.

Parker, R. B., and H. Toots n.d. Trace elements in bones as paleobiological indicators. In: Fossils in the Making. S. K. Behrensmeyer and A. P. Hill, eds. University of Chicago Press, Chicago, in press.

Peebles, C. S. 1971 Moundville and surrounding sites: some structural considerations of mortuary practices II. Am. Antiq. Mem., 25: 68-91.

1974 Moundville: The Organization of a Prehistoric Community and Culture. Doctoral Dissertation, University of California, Santa Barbara.

Peebles, C. S., and S. M. Kus 1977 Some archaeological correlates of ranked societies. Am. Antiq., 42: 421-448.

Perkin-Elmer 1971 Analytical Methods for Atomic Absorption Spectrophotometry. Norwalk, Connecticut.

Posner, A. S. 1969 Crystal chemistry of bone mineral. Physiol. Rev., 49: 760-792.

1973 Bone mineral on the molecular level. Fed. Proc., 32: 1933-1937.

1977 The Relation of Synthetic Amorphous Calcium Phosphate to Bone Mineral Structure. Paper presented before the American Academy of Orthopaedic Surgeons, Las Vegas.

Posner, A. S., and F. Betts 1975 Synthetic amorphous calcium phosphate and its relation to bone mineral structure. Acc. Chem. Res., 8: 273-281.

Posner, A. S., N. C. Blumenthal and F. Betts 1976 Structure and stabilization of cytoplasmic amorphous calcium phosphate. Trans. Orthop. Res. Soc., 1: 127.

Posner, A. S., N. C. Blumenthal, A. L. Boskey and F. Betts 1975 Synthetic analogue of bone mineral formation. J. Dent. Res. 54, Spec. Issue B: B88-B93.

Reed, C. A., ed. 1978 Origins of Agriculture. Mouton, The Hague.

Reeve, J., and R. Hesp 1976 A model-independent comparison of the rates of uptake and short term retention of calcium 47 and strontium- 85 by the skeleton. Calcif. Tissue, 22: 183-189.

Robinson, J. T. 1963 Adaptive radiation in the australopithecines and the origin of man. In: African Ecology and Human Evolution. F. C. Howell and F. Bouriere, eds. Aldine Publ. Co., Chicago, pp. 385-416.

Rosenthal, H. L. 1963 Uptake, turnover and transfer of bone seeking elements in fishes. Ann. N.Y. Acad. Sci., 109: 278-293.

Saxe, A. A. 1970 Social Dimensions of Mortuary Practices. Doctoral Dissertation. University of Michigan, Ann Arbor.

Schoeninger, M. J. 1979 Dietary Reconstruction at Chalcatzingo, A Formative Period Site in Morelos, Mexico. Museum of Anthropology, The University of Michigan, Technical Reports. No. 9.

Schroeder, H. A., I. H. Tipton and A. P. Nason 1972 Trace metals in man: strontium and barium. J. Chronic Dis., 25: 491-517.

Service, E. R. 1971 Primitive Social Organization. Second ed. Random House Publ. Co., New York.

Sneath, P. H. A., and R. R. Sokal 1973 Numerical Tax onomy. W. H. Freedman and Co. Publ., San Francisco.

Sokal, R. R., and F. J. Rohlf 1969 Biometry. W. H. Freedman and Co. Publ., San Francisco. 
Sowden, E. M., and S. R. Stitch 1957 Trace elements in human tissue. Estimation of the concentrations of stable strontium and barium in human bone. Biochem. J., 67 . 104-109.

Spadaro, J. A., R. O. Becker and C. H. Bachman 1970 The distribution of trace metal ions in bone and tendon Calcif. Tissue Res., 6: 49-54.

Spores, R. 1965 The Zapotec and Mixtec at Spanish contact. In: Handbook of Middle American Indians. $R$ Wauchope, ed. University of Texas Press, Austin, Vol. 3 , Part 2, pp. 962-987.

Szpunar, C. 1977 Atomic Absorption Analysis of Ar chaeological Remains: Human Ribs from Woodland Mor tuary Sites. Doctoral Dissertation, Northwestern University, Evanston.

Szpunar, C., J. B. Lambert and J. E. Buikstra 1978 Analysis of excavated bone by atomic absorption. Am. J. Phys. Anthrop., 48: 199-202.

Termine, J. D., and A. S. Posner 1967 Amorphous/ crystalline interrelationships in bone mineral. Calcif Tissue Res., 1: 8-23.

Thurber, D. L., J. L. Kulp, E. Hodges, P. W. Fast and J. M. Wampler 1958 Common strontium content of the human skeleton. Science, 128: 256-257.

Toots, H., and M. R. Voorhies 1965 Strontium in fossil bones and the reconstruction of food chains. Science, 149. 854-855.
Turekian, K. K., and J. L. Kulp 1956 Geochemistry of strontium. Geochim. Cosmochim. Acta, 10: 245-296.

Vose, P. B., and H. V. Koontz 1955 The uptake of strontium by pasture plants and its possible significance in relation to the fall-out of strontium-90. Nature, 183: 1447-1448.

Wessen, G., F. Ruddy, C. Gustafson and H. Irwin 1977a Bone Strontium and Barium as Indicators of Diet and Environment. Paper presented to the Society of American Archaeologists, New Orleans. 1977b Characterization of archaeological bone by neutron activation analysis. Archaeometry, 19 200-205.

White, L. A. 1949 The Science of Culture. Grove Press, Inc., New York.

Wright, H. T., and G. A. Johnson 1975 Population, exchange, and early state formation in southwestern Iran Am. Anthrop., 77: 267-289.

Wyckoff, R. W. G., and A. R. Doberenz 1968 The strontium content of fossil teeth and bones. Geochim. Cosmochim. Acta, 32: 109-115.

Yablonskii, M. F. 1971 Use of differences in bone mineral content for identification of corpses. Sb. Nauch. Tr. Vitebsk. Gos. Med. Inst., 14: 368-374.

- 1973 Identificational significance of major and trace elements of human long tubular bones. Sud.-Med. Ekspert., 16: 16-18. 